\title{
Electrochemical Degradation of Bisphenol A Using Different Modified Anodes Based on Titanium in Aqueous Solution
}

\author{
Lin Guil, Haiyang $\mathrm{Jin}^{2}$, Yu Zheng ${ }^{1}$, Ruichao Peng ${ }^{1}$, Yunbai Luo ${ }^{1}$, Ping Yu ${ }^{1, *}$ \\ ${ }^{1}$ College of Chemistry and Molecular Sciences, Wuhan University, Wuhan, Hubei, 430072, People's \\ Republic of China. \\ ${ }^{2}$ Basin Water Environmental Research Department, Changjiang River Scientific Research Institute, \\ Changjiang Resources Commission, Wuhan, Hubei, 430010, People's Republic of China. \\ *E-mail: yuping@whu.edu.cn
}

doi: $10.20964 / 2018.07 .76$

Received: 24 March 2018 / Accepted: 16 May 2018 / Published: 5 June 2018

\begin{abstract}
Electrochemical degradation of bisphenol A (BPA) was researched by using $\mathrm{Ti} / \mathrm{SnO}_{2}-\mathrm{SbO}_{2} / \mathrm{PbO}_{2}$, $\mathrm{Ti} / \mathrm{Ti}_{4} \mathrm{O}_{7}, \mathrm{Ti} / \mathrm{RuO}_{2}$ and $\mathrm{Ti} / \mathrm{RuO}_{2}-\mathrm{IrO}_{2}$ anodes in aqueous solution. The electrochemical degradation conditions were acquired by investigating the effect of different working factors, such as current densities (5-40 mA/cm ${ }^{2}$, initial $\mathrm{pH}$ (3.4-12.0) and different plate distance $(0.5-3 \mathrm{~cm})$. The best performance of BPA degradation and COD removal was obtained with anodes of $\mathrm{Ti} / \mathrm{Ti}_{4} \mathrm{O}_{7}$ and $\mathrm{Ti} / \mathrm{SnO}_{2}-\mathrm{SbO}_{2} / \mathrm{PbO}_{2}$, the $\mathrm{Ti} / \mathrm{RuO}_{2}-\mathrm{IrO}_{2}$ anode exhibited a moderate capability to degrade $\mathrm{BPA}$, and $\mathrm{Ti} / \mathrm{RuO}_{2}$ showed the lowest efficiency in BPA degradation. Samples were separated by high performance liquid chromatography (HPLC), and the intermediates products were identified with mass spectrometry (MS). The pathways and mechanisms of the electrochemical degradation of BPA process were researched and it could be divided into the following three steps. First, the BPA was believed to be attacked by $\cdot \mathrm{OH}$ radical generated from water electrolysis and then decomposed into one-ring aromatic compounds. Subsequently, these one-ring aromatic compounds could be oxidized and converted to short chain aliphatic acids. Finaly, all the intermediate compounds were mineralized into $\mathrm{CO}_{2}$ and $\mathrm{H}_{2} \mathrm{O}$. The $\mathrm{Ti} / \mathrm{Ti}_{4} \mathrm{O}_{7}$ anode had the highest oxygen evolution potential of $2.4 \mathrm{~V}$, for the $\mathrm{Ti} / \mathrm{SnO}_{2}-\mathrm{SbO}_{2} / \mathrm{PbO}_{2}$ anode it was $1.6 \mathrm{~V}$, the $\mathrm{Ti} / \mathrm{RuO}$ and $\mathrm{Ti} / \mathrm{RuO}_{2}-\mathrm{IrO}_{2}$ anodes had similar oxygen evolution potentials of $1.1 \mathrm{~V}$ and $1.2 \mathrm{~V}$, respectively. By comparing the different electrodes, the $\mathrm{Ti} / \mathrm{Ti}_{4} \mathrm{O}_{7}$ anode have high oxygen evolution potential and a good performance of organic degradation, it is strong potential material for effective electrochemical degradation of BPA and other similar structure of organic pollutants in wastewater.
\end{abstract}

Keywords: Bisphenol A (BPA); Electrochemical degradation; $\mathrm{Ti} / \mathrm{Ti}_{4} \mathrm{O}_{7}$; Hydroxyl radical; Mechanism; 
(C) 2018 The Authors. Published by ESG (www.electrochemsci.org). This article is an open access article distributed under the terms and conditions of the Creative Commons Attribution license (http://creativecommons.org/licenses/by/4.0/). 